\title{
Accounting
}

\section{An Investigation on value chain cooperation attributes in fisheries micro-enterprises}

\author{
Anna Maria Ngabalin ${ }^{a^{*}}$
}

${ }^{a}$ Fisheries Agribusiness Study Program, Tual State Fisheries Polytechnic, Indonesia

\begin{tabular}{l}
\hline C H R O N I C L E \\
\hline Article history: \\
Received November 202019 \\
Received in revised format \\
December 272019 \\
Accepted February 192020 \\
Available online \\
February 192020 \\
\hline Keywords: \\
Fisheries \\
Value chain \\
Data mining \\
Kei islands
\end{tabular}
\begin{abstract}
A B S T R A C T
As in agriculture, fisheries sector faces long list of uncertainty and unsustainability in supply of the products. This is due to the great possibility of natural disaster and moral hazard by the actors in fisheries which lead to the instability of value chain on fisheries commodity from downstream to upstream. Thus, a study must be done in order to explore and minimize the disturbance of the stream of value chain in fisheries. This study aims to investigate the attributes playing big role on affecting value chain cooperation among actors in fisheries commodity in Kei Islands. Data mining is used on the study to determine factors playing major roles in smoothing cooperation in value chain of fisheries commodity, with 220 datasets obtained from actors in fisheries micro-enterprises in Kei Islands taken from August to November, 2019. The result shows that, on average, weights of four data mining techniques; namely support vector machine, fast large margin, logistic regression, naïve bayes and generalized linear model all appear to put management as the leading factor that contributes the most for the cooperation of value chain of fisheries commodity in Kei Islands. This finding implicates that management on all micro-enterprises of fisheries business in Kei Islands has to be the main focus, which is mainly related to basic knowledge on conducting cooperation and maintaining relationship among all actors in fisheries sector, therefore, NGO and local government need to step in and play role on educating all actors for better good governance of the business to obtain the great sustainability in the value chain of fisheries commodity in the region.
\end{abstract}

\section{Introduction}

Indonesia is a maritime country with three quarters of the territory occupied by water. The total area of Indonesian water is approximately 5.8 million $\mathrm{Km}^{2}$, the coastline along the $95,181 \mathrm{Km}$ is the second longest in the world with a total of 17,504 islands. This geographical condition holds considerable potential for fisheries resources both in quantity and diversity. These abundant resources make Indonesia have a comparative advantage in the marine and fisheries sector. The Kei Islands are located within the coral triangle water in eastern part of Indonesia, which means that the biodiversity of the water in the Kei Islands is very high and it is one of the highest in the world. Currently based on research conducted by Picaulima et al. (2017) on average in villages in the coastal areas of the Kei Islands, the amount of money in circulation is in the range of IDR 160 million / month arising from fisheries activities which are mostly contributed by capture fisheries. This value if divided by the number of residents and the number of dependents of the family, on average could reach about IDR 500K/ family per month. While on the other hand, research conducted by Teniwut (2016) shows that capture fisheries resources in Maluku Province in general

* Corresponding author.

E-mail address: edha_143@yahoo.com (A. M. Ngabalin) 
including the Kei Islands territorial water experience a declining trend and are predicted to continue to decline for the next 8-10 years. By considering this condition, based on coastal communities' welfare and economic conditions in this region, there has been no significant contribution of high resources and their welfare.

The ineffectiveness of effective management of capture fisheries resources is also due to the socio-economic characteristics of coastal communities including capture fishermen in this region where the results of research conducted by Teniwut and Teniwut (2018) and Hamid et al. (2017) show that the majority of fisheries businesses in the Kei Islands region had junior high school education and below and more drop out with an average age of over 40 years. This, of course, will lead to the ability of capturing fishermen to improve the performance of the catch because they still run their business in a way that is still traditional. In addition, a study by Teniwut and Teniwut (2018) mentioned access to technology, whereas Teniwut et al. (2017a) stated lack of capabilities of communities in the region to conduct basic business and management in fisheries, aside of various other reasons likes conflict among communities (Teniwut et al., 2017); knowledge (Teniwut et al., 2017), geographical location in Kei Islands (Teniwut et al., 2019; Teniwut et al., 2019) and interconnection with other region in country (Teniwut, 2019) are the causes that hold development of economic welfare of coastal communities in Kei Island.

Business competition is getting tighter as a result of the enactment of free trade has been shifting the business paradigm of comparative advantage into competitive advantage, forcing the business activities / companies choose the right strategy. Thus, value chain strategy is one approach to follow. Value chain management includes all activities carried out in transforming raw materials into products that are sold and consumed. This includes understanding that there is added value at every point in the chain. Value chain analysis is carried out to assess all activities and stakeholders and their relationships in the supply chain, with the aim of helping to mediate inefficiencies such as variability, reduce vulnerability and increase capacity to adapt to change (Vermulen et al., 2008). In reality, value chain cooperation in Kei islands is facing greater constrain from the downstream in particular due to reasons previously mentioned whereas quality and quantity of fisheries commodity of coastal communities are varies during times, whereas on the upstream the connectivity with other islands and cities in the countries also affect the consistency of product and prices and value received by local fishermen and perceived by manufacture in the countries. The disparity of prices of fisheries commodity from Kei Islands to other cities in Indonesia is known to be too wide, as Teniwut and Kabalmay (2015) mentioned about the noncompetitive of prices of seaweed in the region compared with seaweed price of other regions in the country is one of the great problems to be solved, which according to Teniwut et al (2017) is due to asymmetric information between actors in supply chain. Therefore, any study on maintaining a tight and beneficial cooperation among actors in stream of fisheries product in Kei Islands is important not only for increasing the quality of fisheries commodity of the region but also for increasing the welfare of coastal community in Kei islands.

This study aims to investigate the attributes that play in role on affecting value chain cooperation among actors in fisheries commodity in Kei Islands. By doing so, five attributes that affect the cooperation value chain namely socio-economy, psychological, management, policy and cooperation intention are analyzed using data mining approach to predict and obtain the most important and crucial weight of these attributes for the smoothness of value chain of fisheries commodity in the region. The data mining approach has been currently used in various of study fields. For instance Thiede et al. (2019) used data approach in battery production chain, Wang and Yue (2017) used data mining technique in food system, Ni et al. (2007) used it for supplier selection, Holimchayachotikul and Phanruangrong (2010) implemented it for demand forecasting in food industry, Thomassey (2017) on sales forecasting and Lie et al. (2011) on e-business. This evidence proves that data mining is useful and powerful to obtain the useful and important information on related problem.

The rest of the paper is organized in the following manner. The section 1 is introduction, whereas theoretical framework on the related study are given in Section 2. Section 3 presents methodologies used in the study. The result is presented in Section 4. Section 5 discusses the results from the evaluation and Section 6 concludes by summarizing the findings and managerial implications are identified.

\section{Theoretical framework}

A study from Clements et al. (2008) used a theoretical framework of value chain study characterized as relationship connectors between parties, moreover and found that relationships in the chains were characterized by a very strong information exchange, relatively strong cooperative norms, strong operational linkages and specific buyer-seller adaptations. Lawson et al. (2008) conducted a study in New Zealand to see how farmers create value through cooperation. They found that over 80 per cent of the traders at the markets were involved in some form of cooperative activity, reinforcing the idea of markets as community-based activities with high levels of interdependence amongst participants. Cooperation could be identified in different categories and increased over the length of time of trading at the market but could not be directly related to performance or the reasons traders offer for doing business at the market. Dijk and Klep (2005) viewed cooperation among independent entrepreneurs that work together and "win the game" on the market. In addition, they talk about how cooperation can really add value. Moreover, they 
stated that when the market fails and the ways in which cooperation can offer a solution for individual entrepreneurs to have a good position in the market. They show that the two important goals of a cooperative are entrepreneurial success of the group and the members. More intense and better cooperation between actors in value chain can boost the level of knowledge capabilities and innovation in addition to lower transaction cost (Dyer, 1997; Lazzarini et al. 2001), also enhancing the performance of product and actors on value chain (Hewett \& Bearden, 2001; Smith et al., 1995). In fisheries sector the basic cooperation attribute should be socio-economy since it is related most to coastal communities, the other four attributes in that have great contribution to value chain cooperation and among actors in fisheries commodity chain are policy, management, cooperation intention and psychology of each actors.

\section{Methodology}

This study uses a questionnaire as a tool for field data collection, where the object of research is the actors associated with the flow of value chains in fishery commodity transactions in the Kei Islands. Fishermen, aquaculture farmers, sellers, distributors and capital owners up to users with a total of 220 respondents. The data collection process begins in August until November 2019. Data mining has been used in this study to analyze the data. The data mining process uses the data preparation process by Han et al. (2012) which starts with data cleaning and data integration to remove noise and inconsistent data, then continues with data selection, data transformation into forms accordingly to be used data mining technique.

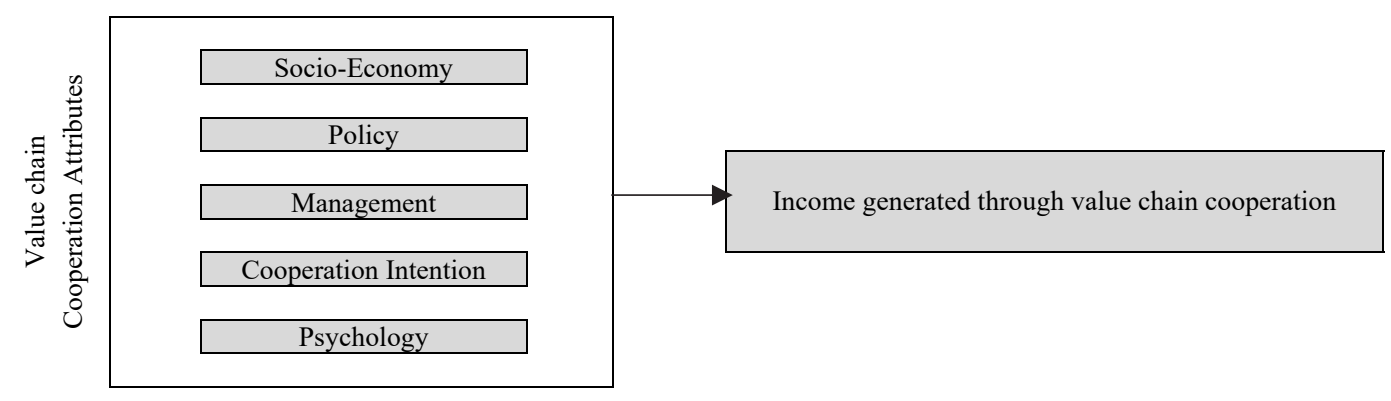

Fig. 1. Theoretical Framework

\section{Data Mining: Clustering and Weight Attributes}

Prediction in data mining is a scientific process to gain knowledge systematically based on physical evidence. In this study, support vector machine as tools for prediction and x means cluster for classification is used. Support Vector Machine (SVM) is a selection method that compares standard parameters of a set of discrete values called candidate sets, and takes the one that has the best classification accuracy (Dong et al., 2007). Support Vector Machine (SVM) is one of the most influential and powerful tools for solving classifications (Burges, 1998). The Support Vector Machine (SVM) concept can be explained simply as an attempt to find the best Hyperplane that functions as a separator of two classes on input space. For n-dimensional space, input data $x_{i}(i=1 \ldots k)$, which belongs to class 1 or class 2 and the associated label becomes -1 for class 1 and +1 for class 2 . The accuracy of the model that will be generated by the transition process with SVM is very dependent on the kernel function and parameters used (Parapat \& Furqon, 2018). Whereas, X-Means clustering is used to solve one of the main weaknesses of Kmeans clustering, namely the need for prior knowledge about the number of clusters $(\mathrm{K})$. In this method, the true value of $\mathrm{K}$ is estimated in an unattended manner and only based on the data set itself.

\section{Results and Discussion}

\subsection{Classification attributes of value chain cooperation}

Based on cluster calculation with $\mathrm{x}$ means, it is obtained that, there are 4 cluster value chain cooperation attributes from actors in the value chain fisheries commodity in Kei Islands. The first cluster consisted of 33 datasets with an average income of $259.98 \%$ higher than other datasets in the other three clusters with lower management and psychology attributes at an average of $31 \%$. The second cluster has datasets where the income is lower by $54 \%$ compared to other datasets in other clusters with also low value chain cooperation attributes such as management and psychology which are 66 datasets. For the third cluster, the management attributes have an average value of $152.13 \%$ greater than the datasets in the other clusters with a positive management and socioeconomic attribute value of 25 datasets. In the fourth cluster of 95 datasets, the average income was $93.12 \%$ lower than the datasets in other clusters, despite having positive attribute values on management and psychology. 
Table 1

X means summary

\begin{tabular}{|c|c|c|c|}
\hline \multirow{2}{*}{$\begin{array}{l}\text { Cluster } \\
\text { Cluster } 1\end{array}$} & Criteria & Number datasets & Average Distance \\
\hline & $\begin{array}{l}\text { Income: } 259.98 \% \text { Larger } \\
\text { Management } 31.76 \% \text { Smaller } \\
\text { Psychology: } 31.03 \% \text { Smaller }\end{array}$ & $33(15 \%)$ & 1.179 \\
\hline Cluster 2 & $\begin{array}{l}\text { Income: } 54.17 \% \text { Smaller } \\
\text { Management } 60.70 \% \text { Smaller } \\
\text { Psychology: } 54.32 \% \text { Smaller }\end{array}$ & $66(30 \%)$ & 2.481 \\
\hline Cluster 3 & $\begin{array}{l}\text { Income: } 152.13 \% \text { Larger } \\
\text { Management } 61.05 \% \text { Larger } \\
\text { Socio Economy: } 63.18 \% \text { Larger }\end{array}$ & $25(11 \%)$ & 8.208 \\
\hline Cluster 4 & $\begin{array}{l}\text { Income: } 93.12 \% \text { Smaller } \\
\text { Management 30.18\% Larger } \\
\text { Psychology: } 38.30 \% \text { Larger }\end{array}$ & $95(43 \%)$ & 0.630 \\
\hline
\end{tabular}

The dataset on the first computer looks like a contradiction in which income is high but with low management and psychology, but in reality these groups of datasets are actors in the value chain that are in an intermediate position between fishermen and fisheries farmers with large distributors in local languages called "papalele" where these actors buy fisheries commodities from fishermen and fisheries farmers to then be brought to the local market and / or middle and big distributors. The characteristics of the actors in the second cluster are traditional fishermen and local fisheries farmers in the Kei Islands, despite having large fish resources, fisherman and fisheries management patterns in this region they are still very low with an average of traditional and standard fishing gear with a narrower scope of operation (Table 1). The third cluster in groups of datasets in this region includes large fishermen and fisheries farmers with good fishing equipment and with a large fleet and capital with good management and good connections with the surrounding community. Usually they lend fishing gear and provide capital to the surrounding community to do fishing business which is more than a portion of their income. The characteristics of datasets in the fourth cluster include fishery processing companies both small and medium, which is because the quality and quantity of fishery raw materials tend to be unstable throughout the year by the fishermen and distributors and the income received tends to be unstable and has been proven to be in the field so far fisheries processing companies in this region have experienced ups and downs over the past decade.

\subsection{Weight of Attributes of Value Chain Cooperation}

In Table 2 below, comparison of data mining performance on four analytical tools approaches namely Naive Bayes, generalized linear models, logistic regression, support vector machines show the three existing criteria; namely accuracy, classification error and $F$ measure, support vector machine has a better level of performance than other three data mining predictive analysis tools. Thus, the weight attribute value chain cooperation value used in this study is the value generated by the support vector machine.

Table 2

Comparison performance criteria

\begin{tabular}{lccc}
\hline \multirow{2}{*}{ Data Mining Technique } & \multicolumn{3}{c}{ Performance criteria } \\
\cline { 2 - 4 } & Accuracy & Classification Error & F Measure \\
\hline Naïve Bayes & $79.1 \%$ & $20.9 \%$ & $86.8 \%$ \\
Generalized Linear Model & $79.5 \%$ & $20.5 \%$ & $88.5 \%$ \\
Logistic regression & $79.5 \%$ & $20.5 \%$ & $88.5 \%$ \\
Support Vector Machine*** & $80.8 \%$ & $19.2 \%$ & $88.0 \%$ \\
\hline *** & & & \\
\hline
\end{tabular}

***Best performance

Based on the results of the study in Table 3, it appears that the management attribute has the highest value in all data mining predictions used. The same value is also shown by support vector machine where the highest weight attribute value of management is 0.053 followed by cooperation intention (0.044) and Socio-Economy (0.043). The results of the research that have been carried out show that the role of management factors in the smooth interaction and relationship processes in the fisheries commodity value chain in the Kei Islands was very crucial. This is because most of the fisheries business operators in this region, both capture fisheries, aquaculture and fisheries processing are still managed traditionally. Lack of good management processes, poor financial accounting, post-production and pre-production production management, poor marketing result in unstable supply of raw and fresh fishery products to distributors and end users. Thus, local governments, NGOs, tertiary education and relevant stakeholders should focus more on improving the ability of business management, especially on fishery 
farmers and fishermen who are in coastal areas in the Kei Islands. Handling problems in accordance with the needs of the community in the field contributes more and is more tangible to improving the welfare of coastal communities that depend on the fisheries sector and at the same time improving the value chain performance cooperation of fisheries commodities in the region.

\section{Table 3}

Weight value among prediction data mining

\begin{tabular}{|c|c|c|c|c|c|}
\hline \multirow[b]{2}{*}{ Data Mining Technique } & \multicolumn{5}{|c|}{ Weight Value } \\
\hline & Management & Socio Economy & $\begin{array}{l}\text { Cooperation } \\
\text { Intention }\end{array}$ & Policy & Psychology \\
\hline Naïve Bayes & $0.222 *$ & $0.137 * *$ & $0.106 * * *$ & 0.078 & 0.063 \\
\hline Generalized Linear Model & $0.660^{*}$ & $0.063 * * *$ & $0.084 * *$ & 0.003 & 0.303 \\
\hline Logistic regression & $0.661 *$ & $0.062 * * *$ & $0.084 * *$ & 0.003 & 0.301 \\
\hline Support Vector Machine & $0.053^{*}$ & $0.043 * * *$ & $0.044 * *$ & 0.015 & 0.031 \\
\hline
\end{tabular}

*Highest **Middle ${ }^{* * * \text { Lower }}$

\section{Conclusion}

Value chain cooperation is very important and crucial among all actors to improve the performance of the value chain flow so that simultaneous income from all fishery actors in the Kei Islands can increase. Like fisheries business actors in general, which is a coastal community that has a low managerial capacity, causing fisheries business activities, especially the supply of fresh products to be inconsistent in quantity and quality. The study has validated the arguments mentioned earlier, where management attributes are the most important attributes and must be resolved immediately by fishery businesses in the upstream part of the value chain, especially in improving the performance of cooperation among fellow actors in the fisheries commodity value chain in this region. The implication of this research for stakeholders is to improve good coordination of management within each actor in the value chain and also improve management cooperation between value chain actors, specifically coordination in production and inventory management from actors upstream to downstream and also coordination management on needs raw materials both in terms of quantity and quality.

\section{References}

Burges, C. J. (1998). A tutorial on support vector machines for pattern recognition. Data mining and knowledge discovery, 2(2), 121-167.

Clements, M. D., \& Price, N. J. (2007). A transfer pricing apparatus for measuring value added along the supply chain: Reflections for internet based inter-organisational relationships. Journal of Internet Business, 4.

Dong, Y., Xia, Z., Tu, M., \& Xing, G. (2007, December). An optimization method for selecting parameters in support vector machines. In Sixth International Conference on Machine Learning and Applications (ICMLA 2007) (pp. 1-6). IEEE.

Dyer, J.H. (1997). Effective interfirm collaboration: How firms minimize transaction costs and maximize transaction value. Strategic Management Journal 18, 535-556.

Hamid, S. K., Teniwut, W. A., Teniwut, R. M., Rahantoknam, M. A., Hasyim, C. L., \& Hungan, M. (2017, October). The Support of MPA (Marine Protected Area) in Coral Triangle Area: Evidence from Kei Islands, Indonesia. In IOP Conference Series: Earth and Environmental Science (Vol. 89, No. 1, p. 012025). IOP Publishing.

Han, J., Pei, J., \& Kamber, M. (2011). Data mining: concepts and techniques. Elsevier.

Hewett, K., \& Bearden, W.O. (2001). Dependence, trust, and relational behavior on the part of foreign subsidiary marketing operations: Implications for managing global marketing operations. Journal of Marketing 65, 51-66.

Holimchayachotikul, P., \& Phanruangrong, N. (2010). A framework for modeling efficient demand forecasting using data mining in supply chain of food products export industry. In Proceedings of the 6th CIRP-Sponsored International Conference on Digital Enterprise Technology (pp. 1387-1397). Springer, Berlin, Heidelberg.

Lazzarini, S. G., Chaddad, F. R., \& Cook, M. L. (2001). Integrating supply chain and network analyses: the study of netchains. Journal on Chain and Network Science, 1(1), 7-22.

Lawson, R., Guthrie, J., Cameron, A., \& Fischer, W. C. (2008). Creating value through cooperation: An investigation of farmers' markets in New Zealand. British Food Journal, 110(1), 11-25.

Liu, B., Cao, S. G., \& He, W. (2011). Distributed data mining for e-business. Information Technology and Management, 12(2), 67-79.

Ni, M., Xu, X., \& Deng, S. (2007). Extended QFD and data-mining-based methods for supplier selection in mass customization. International Journal of Computer Integrated Manufacturing, 20(2-3), 280-291.

Parapat, I. M., \& Furqon, M. T. (2018). Penerapan Metode Support Vector Machine (SVM) Pada Klasifikasi Penyimpangan Tumbuh Kembang Anak. J. Pengemb. Teknol. Inf. dan Ilmu Komput. Univ. Brawijaya, 2(10), 3163-3169. 
Picaulima, S., Teniwut, W. A., Kahfi, S., Teniwut, R. M., Susanti, I. I. D. A. R., \& Hungan, M. \& Ngabalin, AM (2017). Mapping Marine Resources Utilization Based on Seascapes Area: A Study on Gender Comparison. In IOP Conference Series: Earth and Environmental Science (Vol. 89, No. 1, p. 012027).

Smith, K. G., Carroll, S. J., \& Ashford, S. J. (1995). Intra-and interorganizational cooperation: Toward a research agenda. Academy of Management journal, 38(1), 7-23.

Teniwut, W. A. (2019). Challenges in Reducing Seaweed Supply Chain Risks Arising Within and Outside Remote Islands in Indonesia: An Integrated MCDM Approach. In Sustainability Modeling in Engineering: A Multi-Criteria Perspective; Chatterjee, P., Yazdani, M., Chakraborty, S., Eds.; Word Scientific: Singapore, 2019.

Teniwut, W., Marimin, M., \& Djatna, T. (2019). GIS-Based multi-criteria decision making model for site selection of seaweed farming information centre: A lesson from small islands, Indonesia. Decision Science Letters, 8(2), 137-150.

Teniwut, W. A., \& Teniwut, R. M. (2018). Minimizing the instability of seaweed cultivation productivity on rural coastal area: a case study from Indonesia. Aquaculture, Aquarium, Conservation \& Legislation, 11(1), 259-271.

Teniwut, R. M. (2017). Measuring Knowledge Management Capability Condition on the Support of Marine and Fishery Resources Utilisation. International Journal of Management and Applied Research, 4(4), 194-210.

Teniwut, R. M., \& Hasyim, C. L., \& Teniwut, A W. (2017). Resource-Based Capability on Development Knowledge Management Capabilities of Coastal Community. In IOP Conference Series: Earth and Environmental Science (Vol. 89, p. 012017).

Teniwut, W. A., Teniwut, Y. K., Teniwut, R. M., \& Hasyim, C. L. (2017, October). Family vs Village-Based: Intangible View on the Sustainable of Seaweed Farming. In IOP Conference Series: Earth and Environmental Science (Vol. 89, No. 1, p. 012021). IOP Publishing.

Teniwut, W. A., Betaubun, K. D., \& Djatna, T. (2017, October). A conceptual mitigation model for asymmetric information of supply chain in seaweed cultivation. In IOP Conference Series: Earth and Environmental Science (Vol. 89, No. 1, p. 012022). IOP Publishing.

Teniwut, W. A. (2016). For sustainable revenue of fisheries sector in small islands: evidence of Maluku, Indonesia. Aquaculture, Aquarium, Conservation \& Legislation, 9(3), 722-732.

Teniwut, W. A., \& Kabalmay, J. (2015). Emprirical study on evaluation of seaweed cultivation in southeast Maluku. In Prosiding Seminar Ilmiah Tahunan (SIT) Ke-2 Politeknik Perikanan Negeri Tual (Vol. 26, pp. 55-60).

Thiede, S., Turetskyy, A., Kwade, A., Kara, S., \& Herrmann, C. (2019). Data mining in battery production chains towards multicriterial quality prediction. CIRP Annals, 68(1), 463-466.

Thomassey, S. (2010). Sales forecasts in clothing industry: The key success factor of the supply chain management. International Journal of Production Economics, 128(2), 470-483.

Van Dijk, G., \& Klep, L. (2005). When markets fail. Original version in Dutch part of a series. Bedrijfskundige signalementen. Academic service.

Wang, J., \& Yue, H. (2017). Food safety pre-warning system based on data mining for a sustainable food supply chain. Food Control, 73, 223-229.

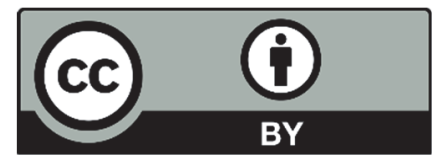

(C) 2020 by the authors; licensee Growing Science, Canada. This is an open access article distributed under the terms and conditions of the Creative Commons Attribution (CC-BY) license (http://creativecommons.org/licenses/by/4.0/). 